\title{
Biological nitrate removal from synthetic wastewater using a fungal consortium in one stage bioreactors
}

\author{
HA Greben ${ }^{1 *}$, L-M Joubert ${ }^{2}$, MP Tjatji ${ }^{1}$, HE Whites ${ }^{2}$ and A Botha ${ }^{2}$ \\ ${ }^{1}$ Natural Resources and the Environment CSIR, PO Box 395, Pretoria 0001, South Africa \\ ${ }^{2}$ Department of Microbiology, University of Stellenbosch, Private Bag X1, Stellenbosch, South Africa
}

\begin{abstract}
A series of lignocellulosic fungi, capable of cellulase and/or xylanase production, were isolated from soil to be used for cellulose degradation and nitrate removal from nitrate-rich wastewater in simple one-stage anaerobic bioreactors containing grass cuttings as source of cellulose. The fungal consortium, consisting of six hyphomycetous isolates, some of which belong to the genera Fusarium, Mucor and Penicillium, was able to remove a significant portion of the nitrate from the treated water. The results were obtained for three bioreactors, i.e. FR, FRp and AFRp, differing in volume and mode of grass addition. Bioreactor AFRp received autoclaved grass, instead of non-autoclaved grass containing natural microbial consortia, as supplied to FR and FRp. Nitrate removal in FR amounted to $89 \%$ removal efficiency, while this was $65 \%$ and $67 \%$ in FRp and AFRp, respectively. The residual chemical oxygen demand (COD) concentration in FR was higher than $600 \mathrm{mg} / \ell$, while it was 355 and $379 \mathrm{mg} / \ell$ in FRp and AFRp, respectively. The similar nitrate removal results for AFRp and FRp indicated that the micro-organisms attached to grass cuttings did not seem to affect the nitrate removal in the reactor. This observation has led to the conclusion that the fungal consortium was, except for being able to degrade cellulose within the grass cuttings, also responsible for nitrate removal from the synthetic nitrate-rich wastewater.
\end{abstract}

Keywords: bioreactors, acetate, cellulose, COD, fermentation, fungi, nitrate removal

\section{Introduction}

Elevated nitrate $\left(\mathrm{NO}_{3}^{-}\right)$concentrations in groundwater, ranging from $150 \mathrm{mg} / \ell$ to $850 \mathrm{mg} / \ell\left(\mathrm{NO}_{3}^{-}-\mathrm{N}\right)$, are a threat to South African communities relying on groundwater as drinking water (Tredoux, 1993; Meyer et al., 1997; Tredoux et al., 2001). Typical toxic responses to nitrate exposure are methaemoglobinaemia (Ergas and Reuss, 2001), abortion and still-born babies (Bruning-Fann and Kaneene, 1993). Therefore simple- to-operate and cost-effective treatment technologies for nitrate removal from nitrate-contaminated groundwater should be investigated

Robertson and Cherry (1995) as well as Blowes et al. (2000) demonstrated passive in situ nitrate removal methods that are mechanically simple and require little maintenance. Waste lignocellulose-containing solids, such as sawdust, grass cuttings and leaf compost, provided the carbon source for heterotrophic denitrification. Filamentous soil fungi of the genus Fusarium are known to utilise such waste materials as carbon source, and are also known for their significant denitrification rates (Guest and Smith, 2002; Shoun et al., 1992). Since the first empirical evidence was obtained on fungal denitrification, numerous biochemical and molecular studies were conducted on this phenomenon, using pure cultures of various fungal taxa obtained from culture collections (Shoun and Tanimoto 1991; Shoun et al., 1992; Kobayashi et al., 1996; Shoun et al., 1998; Tsuruta et al., 1998; Zhou et al., 2002; Kumon et al., 2002; Watsuji et al., 2003).

Recent studies have indicated that, utilising organic carbon compounds as electron source, fungal dissimilatory nitrate reduction may occur via two distinct energy-generating path-

* To whom all correspondence should be addressed.

证 +27 12 841-2278; fax: +27 12 841-2789;

e-mail: HGreben@csir.co.za

Received 5 December 2006; accepted in revised form 1 March 2007. ways (Takaya, 2002). The first respiratory nitrate denitrification occurs under hypoxic conditions and is catalysed by the sequential reactions of nitrate reductase and nitrite reductase, resulting in the formation of nitric oxide - the latter is then reduced via the action of nitric oxide reductase resulting in the formation of the gas nitrous oxide. The second pathway, i.e. ammonia fermentation, occurs under anaerobic conditions and comprises the reduction of nitrate to ammonium, coupled with substrate-level phosphorylation and the catabolic oxidation of electron donors, such as alcohol to acetate (Zhou et al., 2002).

With the above as background, the aim of this study was to isolate a series of lignocellulosic soil fungi, screen them for cellulase and xylanase production, as well as for anaerobic growth. Subsequently, a consortium of these isolates was evaluated for the ability to degrade cellulose, to produce acetate and remove nitrate from a nitrate-containing feed water in a simple one-stage reactor system containing grass cuttings as source of cellulose.

\section{Materials and methods}

\section{Fungal isolation}

Moist chambers ( $1 \ell$ conical flasks) for fungal isolation were prepared by wetting $5 \mathrm{~g}$ autoclaved $\left(121^{\circ} \mathrm{C} ; 15 \mathrm{~min}\right)$ wheat-straw with $15 \mathrm{m \ell}$ filter-sterilised (Sartorius, Minisart; pore size 0.2 $\mu \mathrm{m})$ nutrient solution consisting of $6.7 \mathrm{~g} / \ell$ yeast nitrogen base (YNB, Difco, ref. no. 239210) supplemented with $200 \mathrm{mg} / \ell$ filter-sterilised chloramphenicol (Sigma, Cat. No. C0378-25G). The wetted straw was inoculated with $1 \mathrm{~g}$ compost-rich soil. Five such aluminium-capped moist chambers were each incubated at $25^{\circ} \mathrm{C}$ within a $20 \ell$ plastic bag, along with a $1 \ell$ conical flask containing $100 \mathrm{~m} \ell$ distilled water. After 4 to $14 \mathrm{~d}$ of incubation isolation of fungi was conducted by aseptically transferring 


\begin{tabular}{|l|l|l|l|c|c|c|}
\hline \multicolumn{8}{|c|}{$\begin{array}{l}\text { TABLE 1 } \\
\text { Identity, characteristics and inoculum size of each fungal isolate in the fungal consor- } \\
\text { tium evaluated for removal of nitrate from the fermentation reactors }\end{array}$} \\
\hline $\begin{array}{l}\text { Isolate } \\
\text { no. }\end{array}$ & $\begin{array}{l}\text { Taxon } \\
\text { +Genbank } \\
\text { accession } \\
\text { number }\end{array}$ & ${ }^{*}$ CMC & $\begin{array}{l}\text { * RBB- } \\
\text { xylan }\end{array}$ & $\begin{array}{c}\text { Anaerobic } \\
\text { growth }\end{array}$ & $\begin{array}{c}\text { Dry weight of } \\
\text { inoculum (g) }\end{array}$ \\
\hline V8 & Penicillium corylophilum & EF451579 & 16 & 15 & - & 0.19 \\
\hline V20 & Penicillium citrinum & EF451580 & 8 & 0 & - & 0.19 \\
\hline V25 & Hyphomycetous sp. & - & 8 & 0 & - & 0.06 \\
\hline V30 & Mucor circinelloides & EF451581 & 2 & 7 & + & 0.13 \\
\hline V33 & Hyphomycetous sp. & - & 2 & 7 & - & 0.07 \\
\hline V45 & Fusarium oxysporum & EF451582 & 7 & 0 & + & 0.30 \\
\hline & & & & & & Total inoculum: \\
& & & & & & 0.96 \\
\hline
\end{tabular}

${ }^{+}$Accession numbers at Genbank (www.ncbi.nlm.nih.gov/Genbank) of the PCR products obtained for isolates representing the bulk of the inoculum.

* Diameter (indicated in $\mathrm{mm}$ ) of clearing zones observed on the CMC and the RBB-xylan plates, respectively indicating the relative activity of cellulases and xylanases.

developing fungal mycelia to malt extract agar (MEA, Biolab, Merck Chemicals) plates and incubating them at $30^{\circ} \mathrm{C}$ for $7 \mathrm{~d}$. Single-spore cultures of the fungal isolates were then prepared and maintained on MEA slants at $22^{\circ} \mathrm{C}$.

\section{Screening for fungal cellulase and xylanase activity}

Agar plates containing CMC (carboxy methyl cellulose, Sigma Cat. No. C-5678) (De Koker et al., 2000) and RBB-Xylan [remazol brilliant blue (RBB, Sigma Cat. No. R-8001) covalently linked to Beechwood 4-O-methyl-D-glucurono-D-xylan (Sigma Cat. No. $\mathrm{X}-0502)$ ] (Farkas et al., 1985), respectively, as indicator media were employed to screen potential fungal isolates for activity of cellulases and xylanases - the two major hydrolytic enzyme groups associated with wood degradation. The centre of RBBXylan and CMC plates was inoculated with plugs $(5 \mathrm{~mm}$ diameter) of one-week-old fungal growth on MEA, and incubated at $30^{\circ} \mathrm{C}$ for 1 to $4 \mathrm{~d}$ until fungal growth covered a third of the plate's surface. Xylanase activity was indicated by pale clearing zones surrounding fungal colonies on the RBB Xylan plates. Clearing zones indicating cellulase activity were visible only after flooding (for $15 \mathrm{~min}$ ) with $0.1 \%$ aqueous azo dye congo red (New India Chemical Enterprises, Cochin-24), followed by flooding (for 2 to $3 \mathrm{~h}$ ) with $1 \mathrm{~N} \mathrm{NaCl}$ at $22^{\circ} \mathrm{C}$. Six fungal isolates selected as potentially the best producers of cellulases and xylanases, as indicated by the size of the clearing zones, were thereafter screened for the ability to grow under anaerobic conditions.

\section{Screening for anaerobic fungal growth}

Cultures of each of the six selected fungal isolates were prepared by inoculating a semi-synthetic medium contained in sterile Petri dishes with a plug $(0.5 \mathrm{~cm}$ diameter $)$ of one-weekold growth on MEA. The semi-synthetic medium consisted of yeast extract (Biolab from Merck (Pty) Ltd, South Africa) $(1.0 \mathrm{~g}), \mathrm{MgSO}_{4} .7 \mathrm{H}_{2} \mathrm{O}(0.4 \mathrm{~g})$, glucose (Saarchem from Merck (Pty) Ltd, South Africa) (10.0 g), casamino acids (2.0 g; Bacto, Ref. No. 223050), neopeptone (2.0 g; Difco, ref. no. 223050), agar (18.0 g; Biolab from Merck (Pty) Ltd, South Africa), Cat. No. HG000BX1.500), $\mathrm{NaNO}_{3}^{-}(6.0 \mathrm{~g}), \mathrm{KCl}(0.5 \mathrm{~g}), \mathrm{KH}_{2} \mathrm{PO}_{4}$ $(1.5 \mathrm{~g}), \mathrm{ZnSO} 4.7 \mathrm{H}_{2} \mathrm{O}(44.0 \mathrm{~g}), \mathrm{H}_{3} \mathrm{BO}_{3}(22.0 \mathrm{~g}), \mathrm{MnCl}_{2} .4 \mathrm{H}_{2} \mathrm{O}$ $(10.0 \mathrm{~g}), \mathrm{FeSO}_{4} .7 \mathrm{H}_{2} \mathrm{O}(10.0 \mathrm{~g}), \mathrm{CoCl}_{2} .6 \mathrm{H}_{2} \mathrm{O}(3.4 \mathrm{mg}), \mathrm{CuSO}_{4} .5 \mathrm{H}_{2} \mathrm{O}$ $(3.2 \mathrm{mg}), \mathrm{Na}_{2} \mathrm{MoO}_{4} \cdot 2 \mathrm{H}_{2} \mathrm{O}(3.0 \mathrm{mg})$, EDTA (100.0 mg; Cat. No. $2236020 \mathrm{EM})$, and was dissolved in $1000 \mathrm{m \ell} \mathrm{H}_{2} \mathrm{O}$. All mineral salts used were analytical reagent grade and obtained from major retailers. The inoculated plates were incubated at $22^{\circ} \mathrm{C}$ in anaerobic jars (Oxoid, Hants in UK), in combination with gas generating kits (anaerobic system BR0038B, Oxoid). Aerobic control plates for each isolate were also prepared. After one week of incubation the plates were screened for the presence of developing fungal colonies.

\section{Identification of fungal isolates}

Preliminary identification of the six selected isolates was achieved by using the keys and descriptions of Domsch et al. (1980). Subsequent identification with molecular techniques was achieved by extracting genomic DNA from those isolates representing the bulk of the inoculum to be used for nitrate removal from the synthetic wastewater (Table 1), followed by analyses of the internal transcribed spacer (ITS) region of the ribosomal genes.

Biomass for DNA extraction was obtained by harvesting fungal growth in malt extract broth, incubated at $22^{\circ} \mathrm{C}$ for $5 \mathrm{~d}$, using miracloth (Calbiochem). The biomass was subsequently subjected to quick-freezing in liquid nitrogen, and stored overnight at $-80^{\circ} \mathrm{C}$ before genomic DNA was isolated using the method of Raeder and Broda (1985). The ITS region was amplified by the polymerase chain reaction (PCR) using universal ITS1 (5'TCCGTAGGTGAACCTGCGG-3') and ITS4 (5'-TCCTCCGCTTATTGATATGC-3') oligonucleotide primers as described by White et al. (1990). The PCR reactions were performed by using Taq polymerase (Fermentas) in a Perkin-Elmer 2400 thermal cycler. The conditions under which the PCR reactions were performed are as follows: denaturation for $2 \mathrm{~min}$ at $95^{\circ} \mathrm{C}$ and $30 \mathrm{~s}$ at $94^{\circ} \mathrm{C}$, followed by 30 cycles of annealing for $30 \mathrm{~s}$ at $55^{\circ} \mathrm{C}$, elongation for $1 \mathrm{~min}$ at $72^{\circ} \mathrm{C}$, denaturation for $1 \mathrm{~min}$ at $94^{\circ} \mathrm{C}$ followed by a final elongation step of $5 \mathrm{~min}$ at $72^{\circ} \mathrm{C}$. The PCR products were purified by column chromatography (Nucleospin ${ }^{\mathrm{R}}$ Extract II, Separations) and sequenced using a Perkin Elmer ABI PRISM Model 3100 genetic sequencer. The data from the forward and reverse sequences were compared and aligned by using DNAMAN for WINDOWS Version 4.13 (Lynnon Biosoft). The fungal isolates were identified by comparing known sequences using the BLAST program of the National Center for Biotechnology Information (www.ncbi.nlm.nih.gov/blast). Information on the sequences representing the fungal isolates was subsequently submitted to Genbank (www.ncbi.nlm.nih. gov/Genbank). 


\section{Evaluation of the fungal consortium to remove nitrate from nitrate-rich feed water}

\section{Inoculum preparation}

One-week-old fungal growth of each of the six selected fungal isolates, suspended in autoclaved $\left(121^{\circ} \mathrm{C} ; 15 \mathrm{~min}\right) 100 \mathrm{m \ell}$ malt extract broth (Biolab, Merck Chemicals) that was contained in a sterile $1 \ell$ conical flask and incubated on a rotary shaker (160 $\mathrm{r} / \mathrm{min}$; throw $50 \mathrm{~mm}$ ) at $25^{\circ} \mathrm{C}$, was used to inoculate the three fermentation reactors (FR, FRp and AFRp). The dry weight of the inoculum representing each strain, determined according to the analytical procedures as described for VSS in Standard Methods (1985) is listed in Table 1.

\section{Cellulose degradation by the fungal consortium in absence of nitrate in cellulose degradation reactor (CDR)}

To test the cellulose degradation ability of the fungal consortium, $600 \mathrm{~m} \ell$ fungal consortium was mixed with $500 \mathrm{~g}$ grass cuttings in an anaerobic reactor (Vol. $2 \ell$ ) The contents of the grass reactor were mixed on a daily basis after which samples were taken. The samples were filtered and analysed for the VFA concentration and $\mathrm{pH}$. Tap water $(200 \mathrm{~m} \ell / \mathrm{d})$ was added to replace the volume in the reactor due to sample taking.

\section{Fermentation reactor (FR) with two (non-autoclaved) grass additions}

The fermentation reactor (FR) with a volume of $20 \ell$ (Fig.1) was fed with nitrate-rich $\left(\mathrm{NO}_{3}^{-}-\mathrm{N}: 583 \mathrm{mg} / \ell\right)$ water through an inlet at the bottom of the vessel. The effluent was discharged at the top of the reactor. A $2 \ell$ perforated container filled with grass cuttings was mounted inside the FR. A recycle stream was pumped from the top of the FR through the perforated container, so that the recycle water contacted the partly degraded grass for optimal COD, e.g. acetate, generation (Fig. 1).

The experiment was initiated by mixing inocula from the six fungal isolates with the grass inside the basket of the reactor resulting in a total of $600 \mathrm{~m} \ell$ of fungal inoculum, representing ca. $1.0 \mathrm{~g} \mathrm{(dw)} \mathrm{fungal} \mathrm{mycelium} \mathrm{(Table} \mathrm{1).} \mathrm{The} \mathrm{reactor} \mathrm{was}$ initially operated under batch-mode conditions until nitrate removal was observed. Thereafter FR was fed continuously with nitrate-rich feed water. Fresh grass cuttings ( $250 \mathrm{~g})$ were added on Day 2 and Day 25. The total experimental period was $45 \mathrm{~d}$.

\section{Fungal fermentation reactor (FRp) receiving non- autoclaved grass}

In a repeat study FR was operated for $110 \mathrm{~d}$ similar to the methodology explained above, but now grass cuttings were added on a more regular basis. Initially, $700 \mathrm{~g}$ grass cuttings ( $35 \mathrm{~g}$ grass $/ \ell$ ) were added to FR, whereafter $25 \mathrm{~g}$ grass was added on Days 14, $23,30,37,43,46,51,55$ and 65. From Day 67 to Day 75 the grass addition was $50 \mathrm{~g} / \mathrm{d}$, and $100 \mathrm{~g} / \mathrm{d}$ from Day 75 to Day 110. In this (repeat) study FR was referred to as FRp

\section{Fungal fermentation reactor (AFRp) receiving auto- claved grass}

A $2 \ell$ bioreactor (AFRp) was operated similarly to FRp, but with the grass cuttings autoclaved prior to addition to bioreactor

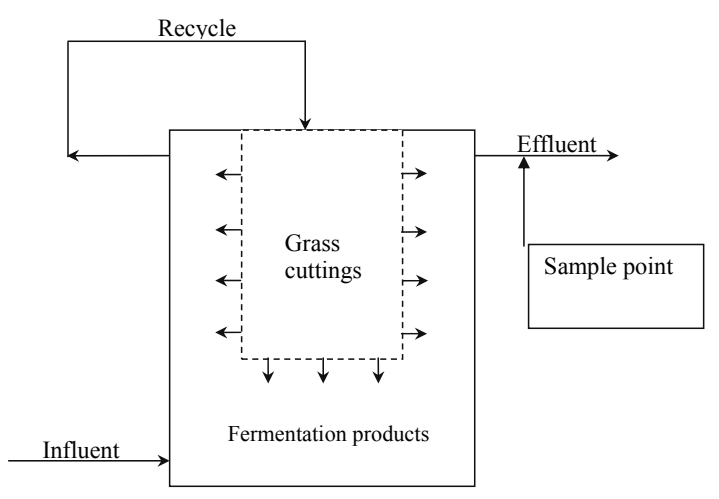

Figure 1

The configuration of the fungal fermentation reactor (FR) used in this study

AFRp. Such elimination of all microbial activity from the grass would indicate the extent to which the fungal consortium was the sole contributor to the denitrification process occurring in FRp. The experimental period of AFRp was $129 \mathrm{~d}$. The AFRp reactor initially received $100 \mathrm{~g}$ grass $/ 2 \ell(50 \mathrm{~g}$ grass $/ \ell)$. Fresh grass (40 g) was added on Days 9, 28, 39, 44, 52, 56, 59, 65, 71 and 80 . Daily grass addition was $10 \mathrm{~g} / \mathrm{d}$ from Days 87 to 94 , and $20 \mathrm{~g} / \mathrm{d}$ from Days 95 to 129 .

\section{Periodic analyses}

Manual determinations of nitrate, $\mathrm{COD}$ and $\mathrm{pH}$ were carried out according to the analytical procedures described in Standard Methods (1985). With the exception of the $\mathrm{pH}$ determination, all analyses were carried out on filtered samples (Whatman No.1).

VFA analyses were conducted using a gas chromatograph (Hewlett Packard HP 5890 Series II) equipped with a flame ionisation detector (FID), while the data were analysed using the Agilent ChemStation ${ }^{\mathrm{TM}}$ software. The column used was an HP-FFAP, $15 \mathrm{~m} \times 0.530 \mathrm{~nm}, 1 \mu \mathrm{m}$. The GC/FID programme can be summarised as follows: initial oven temperature $30^{\circ} \mathrm{C}$, for $2 \mathrm{~min}$, temperature programmed to increase thereafter from $80^{\circ} \mathrm{C}$ to $200^{\circ} \mathrm{C}$ at $25^{\circ} \mathrm{C} / \mathrm{min}$, with temperature hold for $1 \mathrm{~min}$ at $200^{\circ} \mathrm{C}$, FID temperature $240^{\circ} \mathrm{C}$. The carrier gas $\left(\mathrm{N}_{2}\right)$ flow rate was set at $1 \mathrm{ml} / \mathrm{min}$.

\section{Results and discussion}

\section{Identity and characteristics of fungal isolates}

The six fungal isolates showing superior cellulase and xylanase activity were representatives of Mucor and the Hyphomycetes. Some of the latter belonged to the genera Penicillium and Fusarium (Table 1). Screening for anaerobic growth on semi-synthetic medium revealed that the isolates representing Mucor and Fusarium were capable of both aerobic and anaerobic growth, while the isolates representing Penicilium and an as yet unidentified hyphomycetous species was capable of aerobic growth only.

\section{Cellulose degradation of the fungal consortium in absence of nitrate}

Cellulose degradation using the fungal consortium showed that acetate $(160 \mathrm{mg} / \ell$ after $30 \mathrm{~d})$ was produced from grass cuttings to which the fungal consortia had been added (Fig. 2). A number of fungal species are well known for their ability to degrade grass cellulose, producing acetate (Lynd et al., 2002). This acid can be used as electron donor for the biological nitrate removal (Eq. (1)) (Metcalf and Eddy, 1991; Akunna et al., 1993) 


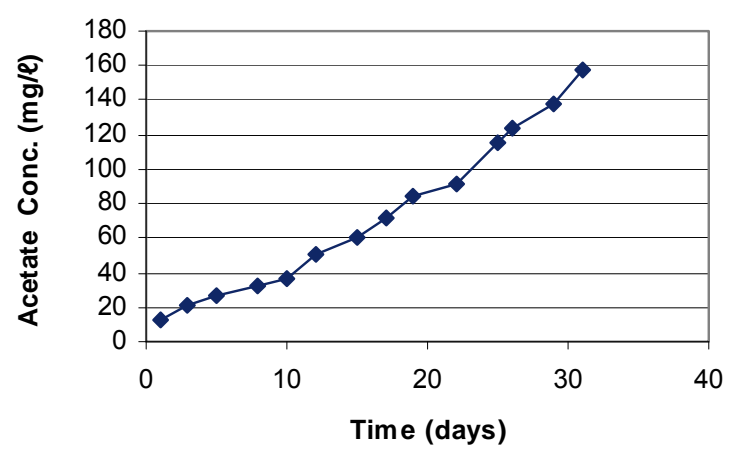

Figure 2

Acetate production from grass cuttings and fungal consortium

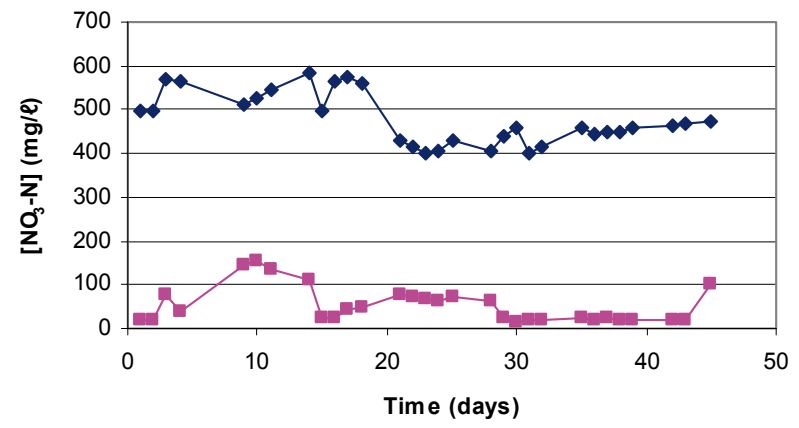

NO3-N feed $w$ ater $\longrightarrow-$ NO3-N treated $w$ ater

Figure 3

Nitrate concentration in feed and treated water in FR over $45 d$

$$
8 \mathrm{NO}_{3}^{-}+5 \mathrm{CH}_{3} \mathrm{COOH} \rightarrow 4 \mathrm{~N}_{2}+10 \mathrm{CO}_{2}+6 \mathrm{H}_{2} \mathrm{O}+8 \mathrm{OH}^{-}
$$

\section{Fermentation reactor (FR) with two (non-autoclaved) grass additions}

Recently, fungi have been recognised to perform denitrification at even greater rates than bacteria (Guest and Smith, 2002). Shoun et al. (1992) found that 9 of the 39 fungi tested for the ability to denitrify, showed complete denitrification to nitrogen gas. In most cases nitrous oxide $\left(\mathrm{N}_{2} \mathrm{O}\right)$ was the product of the denitrification of nitrate or nitrite. In our study nitrate removal was observed in FR (Fig. 3), with the percentage nitrate removal approaching 100\% between Days 29 and 45, and averaging $89 \%$ during the entire experimental period. The graphs in Fig. 3 show that the nitrate concentration in the treated water of FR was generally lower than $100 \mathrm{mg} / \ell$, and notably between Days 29 and 45, when the nitrate concentration in the treated water was $<25 \mathrm{mg} / \ell$. The reactor COD concentrations exceeded $500 \mathrm{mg} / \ell$ during the entire experimental period, mostly being $>800 \mathrm{mg} / \ell$ (Fig. 4), which enabled continuous nitrate removal in FR. These results indicated a strong relationship between high reactor COD concentrations resulting in high nitrate removal efficiency. This finding indicated that part of the available COD, e.g. acetate, was readily usable by the nitrate-removing fungi. The relatively high residual COD concentration comprising other cellulose degradation products, were seemingly not utilised by the fungi for nitrate removal. It can be observed from the VFA profile in FR over time that mainly acetic acid was produced $(600 \mathrm{mg} / \ell)$, which decreased rapidly due to being utilised for nitrate removal (Fig. 5). When fresh grass was added on Day 25, only acetic acid was produced and utilised for nitrate removal during the next $10 \mathrm{~d}$.

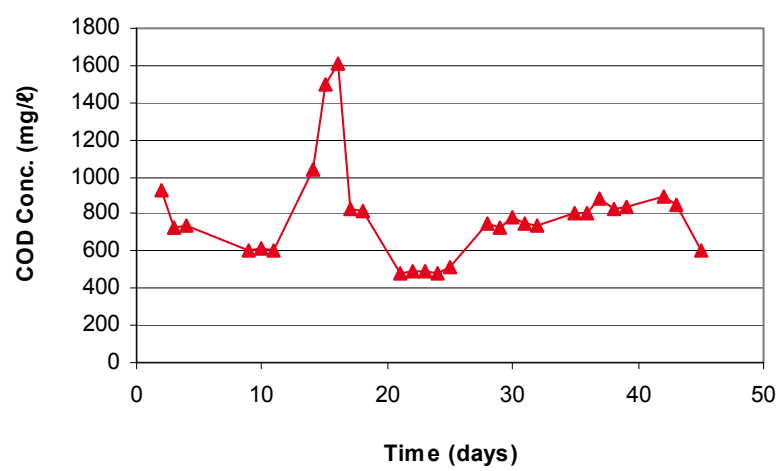

Figure 4

$C O D$ concentration in FR

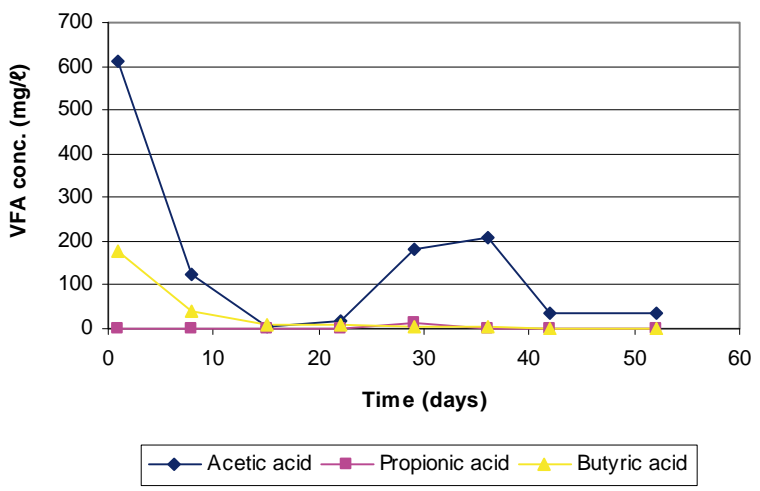

Figure 5

VFA concentration in FR

\section{Fermentation reactor (FRp) with periodic (non-auto- claved) grass additions}

The overall percentage nitrate removal efficiency in FRp was $65 \%$, notably less than the $89 \%$ nitrate removal efficiency recorded for FR. This result can be ascribed to the lower COD concentration in reactor FRp, which was ca. $50 \%$ of the COD concentration in FR (Figs. 4 and 6a). It can be observed from Fig. $6 a$, that the COD concentration in the reactor fluctuated considerable. It was high on days when fresh grass was added, while it decreased due to nitrate removal. The obtained results indicated that in order to achieve sustained nitrate removal, a high reactor COD concentration is required. No residual acetate, propionate or butyrate was detected in FRp during the experimental period, indicating that all VFA produced was utilised as substrate for nitrate removal. The residual COD concentration, measured in the effluent, comprised other cellulose degradation products, which were not utilised by the fungal consortium as carbon and energy source.

\section{Fermentation reactor (AFRp) receiving autoclaved grass periodically}

It can be observed from the graphs in Figs. 7 and 8 that the overall percentage removal efficiency in FR was $65 \%$, while this was $67 \%$ in AFRp. These results indicate that nitrate was indeed removed by fungal consortia, since all grass added to AFRp was autoclaved prior to addition to the reactor. The similar results obtained from both reactors FRp (non-autoclaved grass) and AFRp (autoclaved grass) implied that the denitrifying microbes naturally occurring on the grass played a negligible role in removing nitrate from FRp.

The nitrate removal process carried out by fungi may be ascribed to ammonia fermentation known to occur in anaerobic 

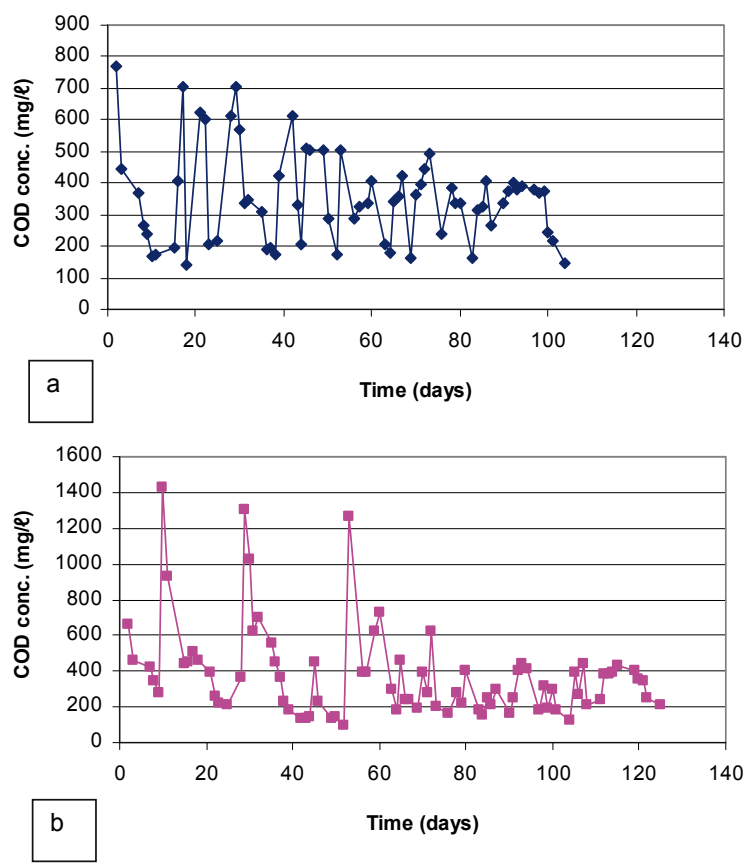

Figure 6

$C O D$ concentration in FRp and AFRp during the experimental periods

cultures of Fusarium oxysporum, comprising the reduction of nitrate to ammonium coupled with substrate-level phosphorylation and the catabolic oxidation of carbon-containing electron donors (Zhou et al., 2002). With the exception of denitrification of $\mathrm{NO}_{3}^{-}$by Fusarium, most fungi reduce only $\mathrm{NO}_{2}^{-}$with $\mathrm{N}_{2} \mathrm{O}$ being the major denitrification product. However, the unique characteristic of fungal co-denitrification, in which fungi can utilise nitrogen compounds other than nitrate/nitrite, and still produce $\mathrm{N}_{2} \mathrm{O}$ and $\mathrm{N}_{2}$, renders fungi more recalcitrant to inhibition (Kumon et al., 2002; Guest and Smith, 2002). This phenomenon is as yet unidentified in bacteria and empirical data suggest that the mechanism of the process differs among fungal groups.

The VFA concentrations in FRp and AFRp were mostly too low to be detected. After an initial stage when the COD concentration in AFRp periodically exceeded that in FRp, similar COD concentrations (ca. $400 \mathrm{mg} / \ell$ ) were observed in both reactors FRp and AFRp (Figs. 6a and 6b). It can be observed from the graphs in Figs. $6 \mathrm{a}$ and $6 \mathrm{~b}$ that fluctuations in COD concentration correlated to the grass addition. Initially the increase in the COD concentration in AFRp was even more pronounced than in FRp, with a higher level of COD being produced than needed for denitrification. When less grass was added more regularly to the reactors, the COD concentration in both reactors became more stable but presumably too low for increased nitrate removal. Figure $6 \mathrm{~b}$ shows that after Day 60, the COD concentration in AFRp was on average $400 \mathrm{mg} / \ell$, which proved to be too low for sustained nitrate removal. When comparing the COD concentration in FR to that in FRp and AFRp, it is evident that in FR a sustained COD concentration could be maintained, while 250 g grass was added only twice. The difference may be ascribed to the longer experimental periods for FRp and AFRp (110 and $129 \mathrm{~d}$, respectively, compared to $45 \mathrm{~d}$ for FR). It can be hypothesised that the fungal consortium lost its cellulose degradation ability with time. It was observed in Figs. $6 a$ and b, that the COD concentrations in FRp and AFRp decreased with time. The results in FR indicated that a residual COD concentration in the treated water is essential for sustained nitrate removal. This cor-

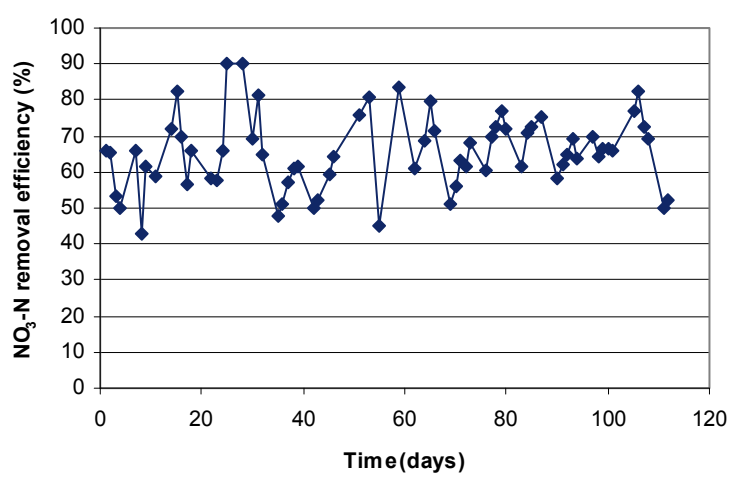

Figure 7

$\mathrm{NO}_{3}{ }^{-}-\mathrm{N}$ removal efficiency (\%) in FRp over $110 \mathrm{~d}$

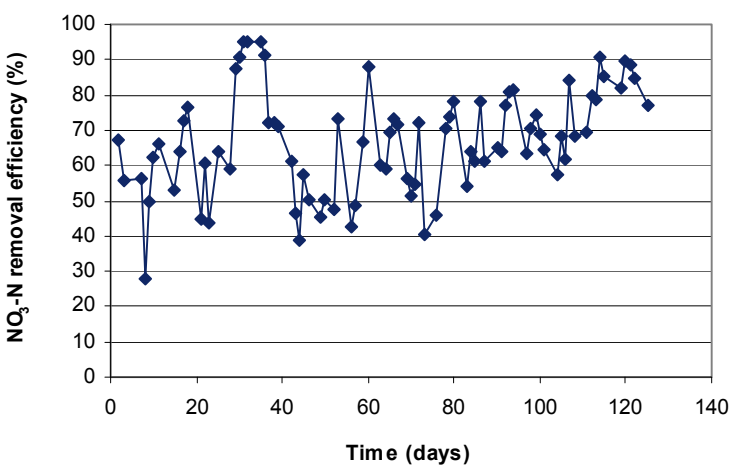

Figure 8

$\mathrm{NO}_{3}{ }^{-}-\mathrm{N}$ removal efficiency (\%) in AFRp over $125 d$

roborates results from other investigations where an additional electron donor was required in situ for effective denitrification to proceed (Ergas and Reuss, 2001; Hendriksen and Ahring, 1996; Nollet and Verstraete; 1996; Korom, 1992).

\section{Evaluation of bioreactor performance in terms of ni- trate removal during the entire experimental periods}

The results, based on the averages of daily sample analyses obtained for the different parameters measured in the three bioreactors, i.e. FR, FRp and AFRp, are listed in Table 2. All three reactors showed satisfactory nitrate removal: $89 \%$ of the nitrate was removed in FR, while the percentage nitrate removal efficiency in FRp and AFRp was $65 \%$ and $67 \%$, respectively. These percentage removal values showed a positive correlation with the COD concentrations in the reactors, which were $790 \mathrm{mg} / \ell$, $355 \mathrm{mg} / \ell$ and $379 \mathrm{mg} / \ell$ for FR, AFRp and FRp, respectively. It can thus be observed from the nitrate removal and the COD concentration in the treated water, that at a relative high residual COD concentration, the percentage nitrate removal increased. These findings support the general contention that organic

\begin{tabular}{|c|c|c|c|}
\hline \multicolumn{4}{|c|}{ 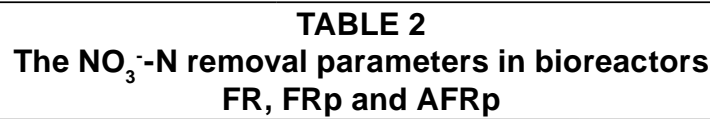 } \\
\hline Parameters & FR & FRp & AFRp \\
\hline $\mathrm{pH}$ & 8.13 & 8.01 & 8.01 \\
\hline $\mathrm{NO}_{3}{ }^{-}-\mathrm{N}$ in $(\mathrm{mg} / \mathrm{\ell})$ & 478 & 390 & 378 \\
\hline $\mathrm{NO}_{3}^{-}-\mathrm{N}$ out $(\mathrm{mg} / \ell)$ & 52 & 135 & 126 \\
\hline $\mathrm{COD}(\mathrm{mg} / \ell)$ & 790 & 355 & 379 \\
\hline $\mathrm{NO}_{3}$-removal $(\mathrm{mg} / \ell)$ & 426 & 255 & 251 \\
\hline$\% \mathrm{NO}_{3}^{-}$removal & 89 & 65 & 67 \\
\hline
\end{tabular}


carbon compounds, measured by COD determination, are used as electron source for fungal nitrate reduction.

Both FRp and AFRp received frequent additions of grass cuttings, but the latter received autoclaved grass instead of non-autoclaved grass containing consortia of naturally occurring microbes. However, similar nitrate removal results were obtained for both these reactors (Table 2). This result indicates that the fungal consortium alone (AFRp) was responsible for the nitrate removal to the same extent as the nitrate removal by a mixed consortium of microbes attached to the grass cuttings, supplemented with the six fungal isolates (FRp) and thus that these six isolates were major contributors to nitrate reduction in the two reactors.

\section{Conclusions}

The results of this study showed that:

- A consortium of lignocellulosic soil fungi, capable of cellulase and xylanase production, can degrade cellulose in grass to produce acetate

- The acetate produced could function as reduced organic electron donors for nitrate removal from nitrate-rich feed water using simple one-stage bioreactors

- The nitrate removal efficiency was dependent on the residual COD concentration in the treated water

- High nitrate removal efficiency of $89 \%$ was achieved in FR

- Comparable nitrate removal efficiencies of $65 \%$ and $67 \%$ were obtained in FRp and AFRp, respectively, when FRp received normal grass additions and AFRp received autoclaved grass additions

- The fungal consortium was responsible for nitrate removal in AFRp.

While it has to be taken into account that the reactor effluent still needs to be treated to decrease the residual COD concentration and to remove microbial biomass before potable water can be obtained, this study showed that cellulose degradation and nitrate removal was due to the activity of a consortium of lignocellulosic soil fungi, capable of cellulase and xylanase production.

\section{References}

AKUNNA JC, BIZEAU C and MOLETTA R (1993) Nitrate and nitrite reduction with anaerobic sludge using various carbon sources. Glucose, glycerol, acetic acid, lactic acid and methanol. Water Res. 27 (8) 1303-1312

BLOWES DW, PTACEK CJ, BENNER SG, McRAE CWT, BENNETT TA and PULS RW (2000) Treatment of inorganic contaminants using permeable reactive barriers. J. Contam. Hydrol. 45 123-137.

BRUNING-FANN CS and KANEENE JB (1993) The effects of nitrate, nitrite and N-nitroso compounds on human health: A review. Vet. Human Toxicol. 35 (6) 521-531.

DE KOKER TH, ZHAO J, ALLSOP SF and JANSE BJH (2000) Isolation and enzymatic characterization of South African white rot fungi. Mycol. Res. 104 820-824.

DOMSCH KH, GAMS W and ANDERSON T-H (1980) Compendium of Soil Fungi. (Vol. 1). Academic Press, London, UK

ERGAS SJ and REUSS AF (2001) Hydrogenotrophic denitrification of drinking water using a hollow fibre membrane bioreactor. J. Water Supply Technol. and Technol.-AQUA 50 (3) 161-171.

GUEST RK and SMITH DW (2002) A potential new role for fungi in a wastewater MBR biological nitrogen reduction system. J. Environ. Eng. Sci. 1 433-437.
HENDRIKSEN HV and AHRING BK (1996) Combined removal of nitrate and carbon in granular sludge: Substrate competition and activities. Antonie van Leeuwenhoek 69 (1) 33-39.

FARKAS VM, LİSKOVÁ and BIELY P (1985) Novel media for detection of microbial producers of cellulase and xylanase. FEMS. Microbiol. Lett. 28 137-140.

KOBYASHI M, MATSUO Y, TAKIMOTO A, SUZUKI S, MARUO F, and SHOUN H (1996) Denitrification, a novel type of respiratory metabolism in fungal mitochondrion. J. Biol. Chem. 271 1626316267.

KOROM SF (1992) Natural denitrification in the saturated zone: A review. Water Resour. Res. 28 (6) 1657-1668.

KUMON Y, SASAKI Y, KATO, I TAKAYA N, SHOUN H. and BEPPUT (2002) Codenitrification and denitrification are dual metabolic pathways through which dinitrogen evolves from nitrate in Streptomyces antibioticus. J. Bacteriol. 184 (11) 2963-2968.

LYND LR, WEIMER PJ, VAN ZYL W and PRETORIUS IS (2002) Microbial cellulose utilisation: Fundamentals and biotechnology. Microbiol. Mol. Biol. Rev. Vol. 66. No 3: 506-577.

METCALF and EDDY (1991) Wastewater Engineering. ( $3^{\text {rd }}$ edn.) New York. McGraw-Hill, Inc.

MEYER JA, CASEY NH and COETZEE CB (1997) Water quality guidelines for livestock watering in Southern Africa. Water SA 23 (1) $7-12$.

NOLLET L and VERSTRAETE W (1996) Gastro-enteric methane versus sulphate and volatile fatty acid production. Environ. Monit. Assess. 42 113-131.

RAEDER U and BRODA P (1985) Rapid preparation of DNA from filamentous fungi. Lett. Appl. Microbiol. 1 17-20.

ROBERTSON WD and CHERRY JA (1995) In situ denitrification of septic-system nitrate using reactive porous media barriers: field trials. Ground Water 33 99-111.

SHOUN H and TANIMOTO T (1991) Denitrification by the fungus Fusarium oxysporum and involvement of cytochrome P-450 ibn the respiratory nitrite reduction. J. Biol. Chem. 266 11078-11082.

SHOUN H, KIM DH, UCHIYAMA H and SUGIYAMA J (1992) Denitrification by fungi. FEMS Microbiol. Lett. 94 277-282.

SHOUN H, KANO M, BABA I, TAKAYA N and MATSUO M (1998) Denitrification by Actinomycetes and purification of dissimilatory nitrate reductase and Azurin from Streptomyces thioluteus. J. Bacteriol. 180 (17) 4413-4415.

STANDARD METHODS (1985) Standard Methods for the Examination of Water and Wastewater $\left(16^{\text {th }}\right.$ edn.) Washington DC.

TAKAYA N (2002) Dissimilatory nitrate reduction metabolisms and their control in fungi. J. Biosci. Bioeng. 94 506-510.

TREDOUX G (1993) A Preliminary Investigation of the Nitrate Content of Groundwater and Limitation of the Nitrate Input. WRC Report No 368/1/93. Water Research Commission, Pretoria, South Africa. $76 \mathrm{pp}$.

TREDOUX G, ENGELBRECHT JFP and TALMA AS (2001) Nitrate in groundwater in Southern Africa. In: K-P. Seiler and S Wohnlich (eds.) New Approaches Characterizing Groundwater Flow (Vol. 1). Balkema, Rotterdam, The Netherlands. 663-666.

TSURUTA S, TAKAYA N, ZHANG L, SHOUN H, KIMURA K, HAMAMOTO M, NAKASE T (1998) Denitrification by yeasts and occurrence of cytochrome P450nor in Trichosporon cutaneum. FEMS Microbiol. Lett. 168 (1) 105-110.

WATSUJI T, TAKAYA N, NAKAMURA A and SHOUN H (2003) Denitrification of nitrate by the fungus Cylindrocarpon tonkinense. Biosci. Biotechnol. Biochem. 67 (5) 1115-1120.

WHITE TJ, BRUNS T, LEE S and TAYLOR J (1990) Amplification and direct sequencing of fungal ribosomal RNA genes for phylogenetics. In: MA Innes, DH Gelfand, JJ Sninsky and TJ Whites (eds.) PCR Protocols. Academic Press, San Diego, USA. 315-322.

ZHOU Z, TAKAYA N, NAKAMURA A, YAMAGUCHI M, TAKEO $\mathrm{K}$ and SHOUN H (2002). Ammonia fermentation, a novel anoxic metabolism of nitrate by fungi. J. Biol. Chem. 277 1892-1896. 